\title{
Renata Borek-Buchajczuk
}

Uniwersytet Marii Curie-Skłodowskiej

renata.borek@wp.pl

\section{Ewolucja zakresu podmiotowego powołania jako podstawy nawiązania stosunku pracy}

\author{
The Appointment of an Employment Relationship - \\ Evolution of its Subjective Scope
}

\section{STRESZCZENIE}

W artykule została podjęta analiza przyczyn wprowadzenia do polskiego porządku prawnego powołania jako podstawy nawiązania stosunku pracy oraz ewolucja jego zakresu podmiotowego. Zapoczątkowana w epoce PRL instytucja powołania jako podstawy pracowniczego zatrudnienia, biorąc pod uwagę zakres podmiotowy jej stosowania i treść stosunku pracy, przebyła długą drogę. Jednocześnie należy stwierdzić, że wciąż sprawdza się w instytucjach i organach, których cechą charakterystyczną działania jest oparcie na sprawdzonych i zaufanych osobach oraz możliwość podjęcia natychmiastowej decyzji o odsunięciu pracownika od powierzonych mu zadań. W artykule wskazano grupy stanowisk objętych powołaniem oraz uzasadnienie pozostawienia tej podstawy nawiązania stosunku pracy w Kodeksie pracy, pomimo daleko idących zmian ustrojowych.

Słowa kluczowe: powołanie, Kodeks pracy

Wybór tematyki niniejszego opracowania nie byt przypadkowy. Pani Profesor Teresa Liszcz przez wiele lat prowadziła badania nad stosunkiem pracy na podstawie powołania, których zwieńczeniem była praca habilitacyjna na temat stosunku pracy dyrektora przedsiębiorstwa państwowego. Rozważania Pani Profesor $w$ tym zakresie, niezwykle cenne i wzbogacajace dorobek doktryny, staty sie również dla mnie asumptem do zajęcia się tą materią.

Zgodnie z treścią art. 2 k.p. źródłem powstania stosunku pracy, oprócz umowy o pracę, są powołanie, mianowanie i wybór.

Powołanie, w przeciwieństwie do umowy o pracę, następuje na podstawie formalnie jednostronnego aktu dokonywanego przez podmiot zatrudniający albo 
inny organ do tego uprawniony, który w tym zakresie działa zamiast podmiotu zatrudniającego. Nie oznacza to, że stosunek pracy jest nawiązywany bez zgody osoby, której dotyczy, bowiem zgoda osoby mającej być pracownikiem zatrudnionym na podstawie powołania stanowi conditio iuris powstania stosunku pracy, stosownie do art. 11 k.p., statuującego zasadę wolności pracy.

Podstawy stosowania powołania jako źródła powstania stosunku pracy, jak wykazuje szczegółowa analiza aktów prawnych okresu międzywojennego, należy poszukiwać w okresie międzywojennym. Po raz pierwszy pojęcie powołania na stanowisko pojawiło się w statucie przedsiębiorstwa państwowego Polskich Lasów Państwowych (zwanego dalej: PLP), który stanowił załącznik do rozporządzenia Prezydenta Rzeczypospolitej Polskiej z dnia 28 czerwca 1924 r. o statucie przedsiębiorstwa Polskie Lasy Państwowe. ${ }^{1}$ To rozporządzenie zostało w części zastąpione rozporządzeniem Prezydenta Rzeczypospolitej z dnia 30 grudnia 1924 r. o organizacji administracji lasów państwowych. ${ }^{2}$

Organami przedsiębiorstwa PLP, którego celem było prowadzenie gospodarki w lasach państwowych, były: Dyrekcja Generalna Lasów Państwowych, dyrekcje okręgowe lasów państwowych oraz nadleśnictwa. Dyrektor Generalny Lasów Państwowych był powoływany przez Ministra Rolnictwa i Dóbr Państwowych, tak jak jego zastępca. W tym ostatnim przypadku następowało to na wniosek Dyrektora Generalnego. Z kolei dyrektorów okręgowych w dyrekcjach okręgowych lasów państwowych i ich zastępców powoływał Dyrektor Generalny. Natomiast nadleśniczy byli powoływani w nadleśnictwach przez Dyrektora Generalnego na wniosek dyrektora okręgowego.

Zgodnie ze statutem przedsiębiorstwa PLP osoby zatrudnione na tych stanowiskach stanowiły ,personel przedsiębiorstwa”, który miał być zatrudniany na podstawie umów o charakterze prywatno-prawnym, zawieranych w przypadku Dyrektora Generalnego i jego zastępcy z Ministrem Rolnictwa i Dóbr Państwowych, a w przypadku pozostałych pracowników - z Dyrektorem Generalnym. Powołanie na stanowisko przewidziane w statucie rodziło zatem więź prawną, której uszczegółowienie następowało w treści umowy. Nie ulega jednak wątpliwości, iż powołanie uprawniało do dokonywania czynności na określonym stanowisku, a więc powierzało funkcję. Bez względu na to, czy przyjmie się, że powołanie, o którym mowa, rodziło stosunek pracy na tej właśnie podstawie, czy też tylko pozwalało pełnić określoną funkcję, podczas gdy stosunek pracy powstawał na podstawie umowy, należy stwierdzić, że było koniecznym warunkiem zatrudnienia na określonych stanowiskach.

Rozporządzenie Prezydenta Rzeczypospolitej z 30 grudnia 1924 r. usunęło z porządku prawnego statut przedsiębiorstwa Polskie Lasy Państwowe i odeszło

\footnotetext{
${ }^{1}$ Dz. U., nr 56, poz. 569, 570.

${ }^{2}$ Dz. U., nr 119, poz. 1079.
} 
od konstrukcji powołania jako formy powierzenia funkcji. Przepis $\S 5$ rozporządzenia przewidywał, iż na czele dyrekcji lasów państwowych stoi dyrektor lub jego zastępca, wyznaczony przez Ministra Rolnictwa i Dóbr Państwowych. Jednocześnie rozporządzenie stanowiło, że stosunki służbowe funkcjonariuszy dyrekcji i nadleśnictw mają charakter publiczno-prawny i stosuje się do nich odpowiednio przepisy ustawy z dnia 17 lutego 1922 r. o państwowej służbie cywilnej. ${ }^{3}$ Rozporządzenie przewidziało mianowanie jako sposób nawiązania stosunku o charakterze publiczno-prawnym. Mogło to być mianowanie do odwołania, z zastrzeżeniem usuwalności (prowizoryczne) oraz na stałe. W administracji lasów państwowych tym samym znalazły zastosowanie przepisy regulujące możliwość odwołania zarządzeniem władzy w każdej chwili pracownika mianowanego do odwołania (prowizorycznie).

W związku z przytoczonymi regulacjami powstało pytanie o przyczynę wprowadzenia powołania jako podstawy nawiązania stosunku pracy do polskiego porządku prawnego. Jak wykazano wyżej, potrzeba istnienia zatrudnienia o charakterze mniej stabilnym, w szczególności opartym na możliwości szybkiego rozstania się z osobą zatrudnioną, istniała już w okresie międzywojennym. Stanowiła ona przeciwwagę dla stabilizacji stosunku służbowego z mianowania na stałe, które było podstawą funkcjonowania służby cywilnej w administracji rządowej w latach 20. i 30. XX wieku w Polsce.

Wykorzystanie powołania jako sposobu nawiązania stosunku pracy nastąpiło w szerokim zakresie w PRL. Przepisy dekretu z dnia 3 stycznia 1947 r. o tworzeniu przedsiębiorstw państwowych ${ }^{4}$, dekretu z dnia 26 października $1950 \mathrm{r}$. o przedsiębiorstwach państwowych ${ }^{5}$ oraz ustawy z dnia 15 lipca 1968 r. o pracownikach rad narodowych ${ }^{6}$ stały się wzorcem rozwiązań przyjętych w tym zakresie w uchwalonym w 1974 r. Kodeksie pracy, choć w nieco zmienionym kształcie.

Powołanie w okresie powojennym stanowiło podstawę nawiązania stosunku pracy osób zajmujących kierownicze stanowiska w znacjonalizowanych przedsiębiorstwach państwowych. Artykuł 11 dekretu z 1947 r. o tworzeniu przedsiębiorstw państwowych stanowił, że dyrekcję przedsiębiorstw powołuje i zwalnia właściwy minister, który uprawnienia te może przekazać podległym sobie organom lub przedsiębiorstwom określonym w art. 2 ustawy. Dekret, o którym wyżej mowa, dawał możliwość tworzenia nie tylko przedsiębiorstw państwowych, których zadaniem było prowadzenie działalności określonego rodzaju (przemysłowej, handlowej, górniczej, świadczenia usług), ale również przedsiębiorstw kontrolujących i nadzorujących funkcjonowanie tych pierwszych, tzw. zjednoczeń.

\footnotetext{
${ }^{3}$ Dz. U. z 1949 r., nr 11, poz. 72, z późn. zm.

${ }^{4}$ Dz. U., nr 8, poz. 42, z późn. zm.

${ }^{5}$ Dz. U. z 1960 r., nr 18, poz. 111, z późn. zm.

${ }^{6}$ Dz. U., nr 25, poz. 164, z późn. zm.
} 
W dekrecie istniało upoważnienie do powoływania i odwoływania dyrektora przedsiębiorstwa państwowego przez dyrektora zjednoczenia.

Rozwinięcie regulacji prawnych dotyczących nawiązania i ustania stosunku pracy osób zatrudnianych na kierowniczych stanowiskach w przedsiębiorstwach państwowych nastąpiło niedługo potem, bowiem w 1950 r., kiedy dekret o tworzeniu przedsiębiorstw państwowych z $1947 \mathrm{r}$. został zastąpiony dekretem z dnia 26 sierpnia 1950 r. o przedsiębiorstwach państwowych. Regulacja w nim zawarta była pełniejsza i bardziej precyzyjna.

Zgodnie z art. 14 dekretu z 1950 r. dyrektor przedsiębiorstwa był powoływany i odwoływany przez ministra, po zasięgnięciu opinii lub na wniosek jednostki nadrzędnej. Zastępców dyrektora i głównego księgowego przedsiębiorstwa powoływał i odwoływał minister na wniosek dyrektora, po zasięgnięciu opinii jednostki nadrzędnej. Minister mógł przekazać sprawę powoływania i odwoływania zastępców dyrektora i głównego księgowego kierownikowi jednostki nadrzędnej. Dotyczyło to tzw. przedsiębiorstw kluczowych, których organem założycielskim był minister.

Oprócz przedsiębiorstw „kluczowych” istniały przedsiębiorstwa terenowe, których dyrektora powoływało i odwoływało prezydium rady narodowej, nadzorujące dane przedsiębiorstwo. Rada Ministrów mogła zastrzec, że powołanie i odwołanie dyrektorów określonego rodzaju przedsiębiorstw terenowych będzie wymagało zgody ministra lub prezydium rady narodowej wyższego stopnia.

Ustawa z dnia 15 lipca 1968 r. o pracownikach rad narodowych rozszerzyła stosowanie powołania jako sposobu nawiązania stosunku pracy na państwową administrację terenową, zaś przyjęte w niej rozwiązania prawne dawały pełniejszy obraz tej instytucji. Ustawa o pracownikach rad narodowych przewidywała, że powołanie stanowi podstawę zatrudnienia pracowników na stanowiskach kierowniczych, określonych przez Prezesa Rady Ministrów, i że jest ono równoznaczne $\mathrm{z}$ zawarciem umowy o pracę na czas nieokreślony (art. 13 ustawy). Ustawa expressis verbis stanowiła, że zatrudnienie takie może mieć miejsce jedynie za zgodą pracownika.

$\mathrm{Z}$ uwagi na zrównanie powołania na stanowisko kierownicze z zawarciem umowy o pracę, nie było problemu z określeniem treści aktu powołania, bowiem akt ten miał odpowiadać treści umowy o pracę, tj. określać stanowisko, na którym pracownik miał być zatrudniony, wskazywać wysokość wynagrodzenia oraz dzień przystąpienia do pracy. Powołania na stanowisko dokonywano w drodze uchwały prezydium rady narodowej. Pracownik powołany na stanowisko kierownicze mógł być z tego stanowiska odwołany przez prezydium rady narodowej.

Odwołanie pracownika ze stanowiska mogło, ale nie musiało, rodzić skutki odnośnie dalszego istnienia stosunku pracy. Odwołanie mogło skutkować jedynie odsunięciem od powierzonej pracownikowi funkcji, bez zamiaru rozwiązywania z nim stosunku pracy. W takiej sytuacji następowało jedynie przeniesienie pra- 
cownika na inne stanowisko pracy, chyba że nie wyraził on na to zgody. W przypadku braku zgody pracownika odwołanie było równoznaczne $\mathrm{z}$ wypowiedzeniem. Natomiast jeżeli odwołanie miało prowadzić do ustania stosunku pracy, wówczas znajdowało to odzwierciedlenie w decyzji o odwołaniu. W tym ostatnim przypadku odwołanie mogło być równoznaczne $\mathrm{z}$ wypowiedzeniem albo rozwiązaniem stosunku pracy bez zachowania okresu wypowiedzenia.

Odwołanie pracownika ze stanowiska kierowniczego było równoznaczne z rozwiązaniem stosunku pracy za trzymiesięcznym wypowiedzeniem i mogło nastąpić tylko z przyczyn określonych w art. 24 ust. 1 ustawy. Enumeratywny katalog przyczyn odwołania zapewniał znaczną stabilność stosunku pracy i w tym aspekcie należy stwierdzić, iż brak było istotnych różnic pomiędzy umownym stosunkiem pracy a stosunkiem pracy z powołania. Ustawa o pracownikach rad narodowych stanowiła, iż odwołanie pracownika powołanego mogło nastąpić jedynie w sytuacjach w niej określonych (np. w art. 16, art. 19 ust. 4 i 5). Wymogiem natury formalnej była konieczność wskazania przyczyny odwołania w uchwale prezydium rady narodowej.

Ponadto pracownicy ci podlegali dodatkowej ochronie płynącej z art. 24 ust. 2 ustawy, zgodnie z którym nie wolno było rozwiązać z nimi stosunku pracy, jeśli pracownikowi brakowało pięć lat do nabycia prawa do emerytury albo pracował w radach narodowych przez okres co najmniej 15 lat, albo przepracował w organach administracji państwowej co najmniej 20 lat, a w tym co najmniej 10 lat w radach narodowych.

$\mathrm{Z}$ uwagi na to, że przyjęta $\mathrm{w}$ ustawie konstrukcja prawna odwołania nie zakładała, o czym wyżej wspomniano, jego skutku w postaci ustania stosunku pracy, lecz możliwą zmianę tego stosunku, to odwołanie prowadziło do rozwiązania stosunku pracy tylko wtedy, gdy w uchwale prezydium rady narodowej skutek ów został wyartykułowany, tzn. zaznaczono, iż odwołanie jest równoznaczne $\mathrm{w}$ danym przypadku $\mathrm{z}$ wypowiedzeniem albo rozwiązaniem stosunku pracy bez zachowania okresu wypowiedzenia.

Charakterystyczne dla tej regulacji było to, iż w przypadku postawienia odwołaniu zarzutu niezgodności z prawem z powodu niezachowania formy pisemnej bądź braku zgody odpowiednich organów na odwołanie, odwołanemu pracownikowi przysługiwały roszczenia restytucyjne. Obok roszczenia o odszkodowanie występowało również alternatywne roszczenie o przywrócenie do pracy, które jednak w przypadku pracowników zatrudnionych na podstawie powołania na stanowiskach kierowniczych realizowało się w postaci przywrócenia do pracy na inne stanowisko $\mathrm{w}$ tym samym prezydium rady narodowej, zgodnie z posiadanymi przez tę osobę kwalifikacjami.

Ustawa o pracownikach rad narodowych przewidywała możliwość nieuwzględnienia roszczenia o przywrócenie do pracy i zasądzenie $\mathrm{w}$ to miejsce przepisanego prawem odszkodowania, w sytuacji gdy przywrócenie do pracy 
pozostawałoby w sprzeczności z interesem społecznym. Przywołana klauzula generalna posiada inne brzmienie niż aktualnie występująca w Kodeksie pracy klauzula niemożliwości lub niecelowości przywrócenia do pracy. Należy jednak stwierdzić, iż w istocie ustawodawcy przyświecał ten sam cel przy tworzeniu jednej i drugiej normy prawnej. Chodziło o umożliwienie organom, rozpatrującym spory na tle odwołań pracowników od czynności rozwiązania z nimi stosunku pracy, kształtowania właściwych relacji międzyludzkich, z uwzględnieniem interesów obu stron stosunku pracy.

Rozwiązania prawne, które wprowadziły dekrety o przedsiębiorstwach państwowych oraz ustawa o pracownikach rad narodowych, były początkiem ekspansji powołania jako podstawy zatrudnienia. Należy pamiętać, że ustawa o pracownikach rad narodowych, choć utorowała drogę powołaniu w administracji państwowej, co do zasady ukształtowała ten stosunek zatrudnienia jako stabilny. Konieczność wskazywania przyczyny odwołania prowadzącego do rozwiązania stosunku pracy oraz możliwość zgłaszania roszczeń restytucyjnych przez odwołanych pracowników na kierowniczych stanowiskach, chroniły trwałość ich stosunków pracy w sposób nie mniej korzystny od dzisiejszej umowy o pracę, a nawet mianowania, które uważa się za najbardziej stabilną podstawę zatrudnienia.

Wprowadzenie powołania do Kodeksu pracy umocniło tę instytucję. Obsadzanie w drodze powołania niemal wszystkich stanowisk kierowniczych w tzw. zakładach pracy, zgodnie z treścią art. 68 k.p. w pierwotnym brzmieniu, otworzyło drogę do bezpośredniego wpływania przez organy nadzorujące te zakłady na ich działania i podejmowane przez nie decyzje. Umożliwiła to przede wszystkim regulacja odwołania jako sposób rozwiązania stosunku pracy z powołania. Brak obowiązku wskazywania przyczyny przy dokonywaniu tej czynności, pozbawienie pracownika roszczeń restytucyjnych, a do niedawna także odszkodowawczych, doprowadziło do ukształtowania powołania jako sposobu zatrudnienia, przy pomocy którego realizuje się przede wszystkim cele polityczne. Na okoliczności te zwraca się uwagę w literaturze, krytycznie oceniając tę podstawę zatrudnienia. $^{7}$

Pod względem ochrony trwałości stosunku pracy nawiązanego na podstawie umowy o pracę, nie wspominając o mianowaniu, powołanie znacznie odbiega od modelu stabilnego zatrudnienia. Taki stan rzeczy wiąże się z istotą powołania i jego celem. Należałoby wyjść od tego, iż istnieje katalog stanowisk, które z uwagi na przypisany im zakres obowiązków i specyficzne umiejscowienie organizacyjne wymagają obsadzenia ich osobami, co do których nie ma wątpliwości, że nałożone na nich zadania będą wykonywały dobrze, a przede wszystkim wzajemne relacje stron będzie cechowała lojalność. Dotyczy to organów administracji rządowej lub samorządowej oraz strategicznych gałęzi gospodarki. Posia-

${ }^{7}$ W. Sanetra [w:] Prawo w XXI wieku. Księga pamiatkowa 50-lecia Instytutu Nauk Prawnych $P A N$, red. W. Czapliński, Warszawa 2006, s. 748-760. 
danie wpływu na osoby zatrudnione na takich stanowiskach, które albo wyposażono we władztwo pochodzące od aktualnej władzy państwowej, albo któremu powierzono wykonywanie zadań mających bezpośredni lub pośredni wpływ na funkcjonowanie krajowej gospodarki, jest dogodnym sposobem realizacji celów i programów założonych przez podmioty prowadzące i nadzorujące te jednostki. W charakterystykę tę dobrze wpisuje się właśnie powołanie jako podstawa nawiązania stosunku pracy oraz towarzyszące mu mechanizmy, które pozwalają bez przeszkód realizować założone cele, choćby to było związane z potrzebą zastąpienia pracowników zatrudnionych na tych stanowiskach. Wiadomo, że powołanie nie występuje na stanowiskach szeregowych, ale w większości tam, gdzie istnieje potrzeba utrzymywania odpowiedniej kadry, przede wszystkim kierowniczej, której zadaniem jest realizacja programów określonych przez podmiot nadzorujący.

Osoba odwołana ze stanowiska dlatego, że nie spełnia oczekiwań stawianych przez podmiot, który ją powołał, z uwagi na wyłączenie przez Kodeks pracy roszczeń restytucyjnych, nie powróci na zajmowane wcześniej stanowisko, dzięki czemu podmiot zatrudniający może obsadzić to stanowisko osobą zaufaną i przy jej pomocy realizować swoje cele. Zazwyczaj z osiągnięcia tych celów, które często znane są całemu społeczeństwu, jest rozliczany i dlatego dąży do ich urzeczywistnienia, bo tylko to daje mu szansę pozytywnego odbioru w opinii publicznej. W PRL niemal cała gospodarka funkcjonowała w oparciu o majątek państwowy, zaś przedsiębiorstwa państwowe i inne jednostki zatrudniające pracowników należały do kręgu tzw. uspołecznionych zakładów pracy. Dlatego uznano za konieczne stosowanie powołania jako podstawy zatrudnienia na stanowiskach kierowników i ich zastępców we wszystkich zakładach pracy.

Obecnie zakres stanowisk objętych tą podstawą nawiązania stosunku pracy uległ znacznemu zawężeniu. Na wstępie należy zauważyć, że stanowiska pracy obsadzane na podstawie powołania nie zostały skatalogowane w jednym akcie prawnym, tylko w wielu ustawach regulujących działalność określonych podmiotów (instytucji). Dodatkowo zagadnienie utrudnia fakt istnienia tzw. powołań pozornych, które $\mathrm{w}$ istocie nie rodzą stosunku pracy na podstawie powołania, a jedynie powierzają określone stanowisko osobie już wcześniej zatrudnionej ${ }^{8}$, albo powołań, które dotyczą zatrudnienia na innej podstawie prawnej (najczęściej na podstawie mianowania).

Niewątpliwie z powołaniem jako sposobem nawiązania stosunku pracy mamy do czynienia w tym przypadku, gdy ustawodawca wyraźnie stanowi, że stosunek pracy na danym stanowisku powstaje właśnie w taki sposób. W literaturze dla potrzeb rozróżnienia stosunków prawnych przyjmuje się między innymi metodę

${ }^{8}$ Zob. zwłaszcza: P. Kłosiewicz, Instytucja powołania a powołanie pozorne, „Państwo i Prawo” $1966, \mathrm{nr} 6$. 
delimitacji formalnej i delimitacji „,merytorycznej”, która polega na dokładnym analizowaniu właściwości danego stosunku prawnego pod kątem różnic i podobieństw do ustalonego wzorca i wyprowadzeniu wniosków z tej analizy. Obie metody mają swoich zwolenników i przeciwników. ${ }^{10}$ Powszechnie przyjmuje się, iż to właśnie metoda „merytoryczna” powinna stać się podstawą oceny, z jakim stosunkiem prawnym mamy do czynienia.

Moim zdaniem, pomimo innych wniosków wysnutych z analizy właściwości stosunku prawnego, nie można ignorować jasnego stanowiska ustawodawcy w danej materii. ${ }^{11}$ Inna sprawa, że ustawodawca często posługuje się niekonsekwentnym aparatem pojęciowym. Jednak wydaje się, że z powołaniem jako sposobem nawiązania stosunku pracy mamy do czynienia tam, gdzie ustawodawca wprost wskazuje na tę podstawę zatrudnienia, nawet jeśli regulacja tego stosunku w konkretnej ustawie zasadniczo odbiega od modelu tego stosunku przyjętego w Kodeksie pracy.

Powołanie jako podstawa zatrudnienia jest przewidziane przede wszystkim w szeroko rozumianej administracji publicznej, z wyłączeniem korpusu służby cywilnej. Na strategicznych stanowiskach państwowych, na których następuje wykonywanie zadań państwa, powołanie jest dobrym narzędziem prowadzenia polityki kadrowej, ponieważ pozwala na sprawne reagowanie w przypadkach nieprawidłowego wykonywania obowiązków poprzez natychmiastowe pozbawienie stanowiska. Powołanie z uwagi na swą niestabilność nie występuje w służbie cywilnej, gdzie stosuje się mianowanie i umowę o pracę ${ }^{12}$, ponieważ cechą służby cywilnej jest jej niezależność polityczna i stabilność.

Powołanie jako podstawa nawiązania stosunku pracy jest przewidziane w kilkudziesięciu innych ustawach i obejmuje w szczególności stanowiska w organach kontroli państwowej (np. stanowisko Głównego Inspektora Pracy, jego zastępców, okręgowych inspektorów pracy i ich zastępców ${ }^{13}$, Głównego Inspektora Ochrony Środowiska, jego zastępców, wojewódzkich inspektorów ochrony środowiska oraz ich zastępców ${ }^{14}$, Głównego, Wojewódzkiego i Powiatowego Inspektora Nadzoru Budowlanego ${ }^{15}$, Głównego Inspektora Sanitarnego i ich zastępców,

\footnotetext{
${ }^{9}$ Por. J. Stelina, Charakter prawny stosunku pracy z mianowania, Gdańsk 2005, s. 47 i nast.

${ }^{10}$ Zob. np. T. Zieliński, Stosunek prawa pracy do prawa administracyjnego, Warszawa 1977.

${ }^{11}$ Zob. stanowisko J. Steliny (ibidem, s. 51), a także R. Borek-Buchajczuk (Powołanie niewtaściwe, „Praca i Zabezpieczenie Społeczne” 2011, nr 1, s. 28-33).

${ }^{12}$ Zob. ustawę z dnia 21 listopada 2008 r. o służbie cywilnej, Dz. U. z 2014 r., poz. 1111, z poźn. $\mathrm{zm}$.

${ }^{13}$ Art. 4 i 5 ustawy z dnia 13 kwietnia 2007 r. o Państwowej Inspekcji Pracy, Dz. U. z 2012 r., poz. 404 , z późn. zm.

${ }^{14}$ Art. 4 i 5 ustawy z dnia 20 lipca 1991 r. o Inspekcji Ochrony Środowiska, Dz. U. z 2013 r., poz. 686 , z poźn. zm.

${ }^{15}$ Art. 86-88 ustawy z dnia 7 lipca 1994 r. Prawo budowlane, Dz. U. z 2013 r., poz. 1409, z późn. zm.
} 
wojewódzkiego inspektora sanitarnego oraz jego zastępców, a także powiatowego inspektora sanitarnego i państwowego granicznego inspektora sanitarnego ${ }^{16}$, wiceprezesów Najwyższej Izby Kontroli oraz dyrektora generalnego Najwyższej Izby Kontroli ${ }^{17}$, Prezesa Państwowej Agencji Atomistyki oraz wiceprezesów ${ }^{18}$, etatowych członków regionalnych izb obrachunkowych ${ }^{19}$, etatowych członków samorządowych kolegiów odwoławczych ${ }^{20}$ ), stanowiska w jednostkach zajmujących się gromadzeniem i przetwarzaniem informacji publicznej (np. stanowisko Prezesa Instytutu Pamięci Narodoweje' ${ }^{21}$ Naczelnego Dyrektora Archiwów Państwowych oraz jego zastępców ${ }^{22}$, Głównego Geodety Kraju ${ }^{23}$ ), stanowiska w jednostkach nadzorujących wykonywanie zadań państwa w zakresie utrzymania infrastruktury (np. stanowisko Prezesa i wiceprezesa Urzędu Regulacji Energetyki ${ }^{24}$, Dyrektora Urzędu Żeglugi Śródlądowejej), stanowiska w jednostkach realizujących zadania państwa w zakresie ochrony zdrowia (np. stanowisko Głównego Lekarza Weterynarii oraz jego zastępców ${ }^{26}$ ), stanowiska w jednostkach oświatowo-kulturalnych (np. stanowisko dyrektora i zastępców dyrektora Narodowego Centrum Badań i Rozwoju oraz kierowników komórek organizacyjnych i ich zastępców ${ }^{27}$, dyrektorów instytucji kultury oraz ich zastępców ${ }^{28}$, wojewódzkich konserwatorów zabytków ${ }^{29}$, niektórych dyrektorów szkół i placówek oświa-

${ }^{16}$ Art. 8 i 11 ustawy z dnia 14 marca 1985 r. o Państwowej Inspekcji Sanitarnej, Dz. U. z 2011 r., nr 212, poz. 1263 z późn. zm.

${ }^{17}$ Art. 20-21 ustawy z dnia 23 grudnia 1994 r. o Najwyższej Izbie Kontroli, Dz. U. z 2012 r., poz. $82 \mathrm{z}$ późn. zm.

${ }^{18}$ Art. 109 ustawy z dnia 29 listopada 2000 r. Prawo atomowe, Dz. U. z 2012 r., poz. 1514.

${ }^{19}$ Art. 26a ustawy z dnia 7 października 1992 r. o regionalnych izbach obrachunkowych, Dz. U. z 2012 r., poz. 1113 z późn. zm.

${ }^{20}$ Art. 7 ustawy z dnia 12 października 1994 r. o samorządowych kolegiach odwoławczych, Dz. U. z 2001 r., nr 79, poz. 856 z późn. zm.

${ }^{21}$ Art. 10 ustawy z dnia 18 grudnia 1998 r. o Instytucie Pamięci Narodowej - Komisji Ścigania Zbrodni przeciwko Narodowi Polskiemu, Dz. U. z 2014 r., poz. 1075 z późn. zm.

${ }^{22}$ Art. 18 ustawy z dnia 14 lipca 1983 r. o narodowym zasobie archiwalnym i archiwach, Dz. U. z 2011 r., nr 123, poz. 698 z późn. zm.

${ }^{23}$ Art. 6b ustawy z dnia 17 maja 1989 r. Prawo geodezyjne i kartograficzne, Dz. U. z 2010 r., nr 193, poz. 1283 z późn. zm.

${ }^{24}$ Art. 21 ustawy z dnia 10 kwietnia 1991 r. Prawo energetyczne, Dz. U. z 2012 r., poz. 1059 z późn. zm.

${ }^{25}$ Art. 7 ustawy z dnia 21 grudnia 2000 r. o żegludze śródlądowej, Dz. U. z 2013 r., poz. 1458 z późn. zm.

${ }^{26}$ Art. 6 ustawy z dnia 29 stycznia 2004 r. o Inspekcji Weterynaryjnej, Dz. U. z 2010 r., nr 112, poz. $744 \mathrm{z}$ późn. $\mathrm{zm}$.

${ }^{27}$ Art. 8 ustawy z dnia 15 czerwca 2007 r. o Narodowym Centrum Badań i Rozwoju, Dz. U. z 2014 r., poz. 1788 z późn. zm.

${ }^{28}$ Art. 15 ustawy z dnia 25 października 1991 r. o organizowaniu i prowadzeniu działalności kulturalnej, Dz. U. z 2012 r., poz. 406 z późn. zm.

${ }^{29}$ Art. 91 ustawy z dnia 23 lipca 2003 r. o ochronie zabytków i opiece nad zabytkami, Dz. U. z 2014 r., poz. 1446. 
towych ${ }^{30}$ ), stanowiska w przedsiębiorstwach państwowych i przedsiębiorstwach użyteczności publicznej (np. dyrektorzy przedsiębiorstw państwowych, ich zastępcy oraz główni księgowi ${ }^{31}$, Dyrektora Generalnego Lasów Państwowych, jego zastępców, Głównego Inspektora Straży Leśnej, dyrektorów regionalnych dyrekcji lasów państwowych, ich zastępców oraz nadleśniczych, leśniczych i głównych księgowych - kierowników jednostek organizacyjnych lasów państwowych ${ }^{32}$ ), stanowiska w terenowych organach administracji publicznej - administracji rządowej i pozarządowej (np. zastępców wójtów, burmistrzów, prezydentów miast, sekretarzy gminy, sekretarzy powiatu, skarbników gmin [głównych księgowych budżetu], skarbników powiatu [głównych księgowych budżetu powiatu], skarbników województwa [głównych księgowych budżetu województwa] ${ }^{33}$, wojewodów i wicewojewodó $w^{34}$ ), stanowiska w Zakładzie Ubezpieczeń Społecznych - w odniesieniu do Prezesa Zakładu Ubezpieczeń Społecznych, kierowników jednostek organizacyjnych Zakładu i ich zastępców oraz głównych księgowych ${ }^{35}$, w sądach - w odniesieniu do dyrektora sądu apelacyjnego, dyrektora sądu okręgowego oraz kierownika finansowego sądu rejonowego i ich zastępców. ${ }^{36}$

${ }^{30}$ Ustawa z dnia 7 września 1991 r. o systemie oświaty, Dz. U. z 2004 r., nr 256, poz. 2572 z późn. zm. Ustawodawca w przypadku dyrektorów placówek oświatowych używa określenia „powierzenie stanowiska”, co rodzi pytanie o rzeczywistą podstawę nawiązania stosunku pracy. W dalszej treści ustawy mowa jest jednak o „odwołaniu” jako sposobie zakończenia stosunku pracy na tym stanowisku. Moim zdaniem sytuacja prawna pracowników zatrudnianych na kierowniczych stanowiskach w placówkach oświatowych będzie zróżnicowana. Pamiętać bowiem należy, że osoba, która wygra konkurs na dyrektora placówki oświatowej, może wywodzić się z kręgu pracowników tej jednostki (tzn. jest tam już zatrudniona na stanowisku nauczyciela, najczęściej na podstawie mianowania) bądź też jest to osoba z zewnątrz, której nie łączy z placówką żaden węzeł prawny. Oznacza to, że w pierwszym przypadku mamy do czynienia z klasycznym powierzeniem stanowiska, którego utrata nie powoduje ustania stosunku pracy. Nauczyciel powraca na dotychczas zajmowane stanowisko pracy. W drugim przypadku dochodzi do nawiązania stosunku pracy na podstawie powołania, i to na czas określony, w związku z kadencyjnością przewidzianą na tym stanowisku przez ustawodawcę. Konsekwencją upływu okresu kadencji lub wcześniejszego odwołania dyrektora ze stanowiska jest ustanie jego stosunku pracy z placówką, w której był zatrudniony przez powołanie. Powyższe stanowisko znajduje odzwierciedlenie w orzecznictwie, w którym uznano, że w przypadku nauczycieli mianowanych, zatrudnionych przed powierzeniem kierowniczego stanowiska w placówce oświatowej, odwołanie ich ze stanowiska stanowi jedynie zmianę treści stosunku pracy, a nie odwołanie, przez co staje się zbliżone do wypowiedzenia zmieniającego.

${ }^{31}$ Art. 33 i 44 ustawy z dnia 25 września 1981 r. o przedsiębiorstwach państwowych, Dz. U. z 2013 r., poz. 1384.

${ }^{32}$ Ustawa z dnia 28 września 1991 r. o lasach, Dz. U. z 2014 r., poz. 1383.

${ }^{33}$ Art. 4 ust. 1 pkt 2 ustawy z dnia 21 listopada 2008 r. o pracownikach samorządowych, Dz. U. z 2014 r., poz. 1202.

${ }^{34}$ Art. 6 i art. 7 ustawy z dnia 23 stycznia 2009 r. o wojewodzie i administracji rządowej w województwie, Dz. U. nr 31, poz. 206 z późn. zm.

${ }^{35}$ Art. 73 ust. 2 i 4 ustawy z dnia 13 października 1998 r. o systemie ubezpieczeń społecznych, Dz. U. z 2015 r., poz. 121.

${ }^{36}$ Art. 4 ust. 3 ustawy z dnia 18 grudnia 1998 r. o pracownikach sądów i prokuratur, Dz. U. z 2011 r., nr 109, poz. 639 z późn zm. 
Analiza przypadków, w których ustawodawca zdecydował o powołaniu jako podstawie zatrudnienia, prowadzi do wniosku, że podstawowym kryterium decydującym o tym sposobie nawiązania stosunku pracy jest szczególna doniosłość funkcji i zadań wykonywanych na powierzanych pracownikom stanowiskach. Należy zauważyć, że powołanie przewidziano na stanowiskach w administracji rządowej, samorządowej oraz sektorze gospodarki państwowej. W niemal wszystkich przypadkach są to stanowiska kierownicze i samodzielne wyższego lub średniego szczebla. Na większości z nich są realizowane jednocześnie zadania o charakterze politycznym. W niemal wszystkich przypadkach polityczny jest również klucz doboru osób na te stanowiska. Prowadzi to do wniosku, że powołanie, jako podstawa nawiązania stosunku pracy, jest zarezerwowane dla istotnych - z punktu wykonywania zadań państwa - instytucji, na które przemożny wpływ mają decydenci polityczni. Takie rozwiązanie determinuje również w większości przypadków charakter aktu powołania. Dokonuje go bowiem z reguły organ władzy publicznej odpowiedniego szczebla, a wraz z powierzeniem stanowiska następuje przekazanie atrybutów władzy w postaci między innymi kompetencji do wydawania aktów administracyjnych, również o charakterze indywidualnym (decyzji administracyjnych).

Należy uznać, że powołanie jest trafnym sposobem zatrudniania, jeżeli dotyczy stanowisk w administracji publicznej (rządowej i samorządowej), z wyłączeniem służby cywilnej, które bezpośrednio wiążą się z wykonywaniem zadań państwa i realizacją założeń i programów politycznych decydentów, jak również w tych przypadkach, gdy stabilność zatrudnienia powinna ustępować przed interesem społeczeństwa i państwa, a więc np. w przypadku tzw. zakładów administracyjnych, które realizują zadania państwa i służą całemu społeczeństwu (szkoły publiczne, szpitale publiczne). Należy jednak stwierdzić, że w niektórych przypadkach stosowanie tej podstawy zatrudnienia nie znajduje uzasadnienia. Wydaje się, że nie jest ona konieczna w celu nadzorowania działalności np. przedsiębiorstwa państwowego. Właściwą podstawą zatrudnienia mógłby być w tym przypadku, w odniesieniu do dyrektora tej jednostki, kontrakt menadżerski, podobnie jak w odniesieniu do jego zastępcy oraz głównego księgowego przedsiębiorstwa. Powołanie powinno znaleźć zatem zastosowanie tam, gdzie trwałość i stabilność zatrudnienia, która wiąże się z innymi podstawami nawiązania stosunku pracy, takimi jak mianowanie i umowa o pracę, sprzeciwia się albo dobru zarządzanej jednostki, albo społeczeństwu, uniemożliwiając realizację celów postawionych przez decydentów. W dobie demokracji i tendencji do „oddawania” władzy przez państwo, powołanie jako podstawa stosunku pracy powinno zostać ograniczone do stanowisk administracji publicznej wysokiego szczebla, na których wykonywane są zadania państwa.

Powyższe wnioski ewoluowały na skutek zmian ustrojowych i systemowych od chwili uchwalenia obowiązującego Kodeksu pracy aż do dnia dzisiejszego. 
Niewątpliwie istota powołania jako podstawy nawiązania stosunku pracy, wykorzystywana $\mathrm{w}$ okresie powojennym i przeniesiona do Kodeksu pracy z tzw. rozwiązań partyjnych, pozostaje jednak ta sama. Stosunek pracy z powołania jest pomyślany jako dogodny instrument kształtowania polityki kadrowej i jako taki powinien być wykorzystany tam, gdzie warunkiem świadczenia pracy jest zaufanie podmiotu nadzorującego lub samego pracodawcy, zaś w przypadku jego braku - natychmiastowe odsunięcie od obowiązków i możliwość zastąpienia pracownika inną osobą w celu zachowania ciągłości zadań na danym stanowisku. Jednocześnie pracownicy zatrudnieni na podstawie powołania doskonale zdają sobie sprawę z charakteru owego zatrudnienia, często obejmując stanowisko na skutek natychmiastowej zmiany na nim, która dotyczyła ich poprzednika. Jeżeli decydują się pretendować, zwykle w procedurze konkursowej, do objęcia tego rodzaju stanowiska, powinni mieć świadomość tego, że tak szybko, jak nastąpiło ich zatrudnienie, może dojść do zakończenia tego stosunku pracy. Oprócz tego istotnym elementem pozwalającym na swobodne kształtowanie kadry przy stosunku pracy z powołania jest brak możliwości skutecznego zgłaszania roszczenia o przywrócenie do pracy. Ten rodzaj roszczenia, o charakterze restytucyjnym, pozostaje poza sferą uprawnień odwołanego ze stanowiska (o ile było to odwołanie zrównane w skutkach z wypowiedzeniem). Pozwala to dysponentom zatrudnienia bez obaw obsadzać stanowisko po odwołaniu, powierzając je osobie, która posiada ich zaufanie.

Należy zauważyć, że w dobie daleko posuniętej ochrony trwałości stosunku pracy, stosunek pracy z powołania jawi się jak swoista „wysepka” swobodnego zatrudnienia, z której chciałby korzystać każdy pracodawca. Powyższe jest przeznaczone tylko w nielicznych regulacjach i powinno znajdować uzasadnienie w charakterze praw i obowiązków, a więc w treści stosunków pracy.

Zagadnienie, o którym mowa, było przedmiotem zainteresowania Szanownej Jubilatki, która w połowie lat 80 . XX wieku podjęła się analizy stosunku pracy dyrektora przedsiębiorstwa państwowego. ${ }^{37}$ Wielokrotnie wskazywała także na potrzebę ograniczenia tej podstawy zatrudnienia, a nawet jej wyeliminowania. ${ }^{38}$ $\mathrm{O}$ ile $\mathrm{z}$ tym ostatnim rozwiązaniem nie zgadzam się, to jednak również opowiadam się za ograniczeniem powołania jako podstawy nawiązania stosunku pracy wyłącznie do stanowisk ,politycznych”, a więc tych, których obsada następuje przy uwzględnieniu potrzeb i konotacji politycznych, partyjnych, jak np. w odniesieniu do ministrów, wojewodów i ich zastępców, zastępców wójtów, burmistrzów i prezydentów, organów administracji publicznej. W pozostałych przypadkach analiza potrzeb pracodawców i charakteru czynności wykonywanych na stanowiskach kierowniczych i zarządzających prowadzi do wniosku, że właściwą

${ }^{37}$ T. Liszcz, Dyrektor przedsiębiorstwa państwowego w PRL, Lublin 1986.

${ }^{38}$ Eadem, Pozaumowne stosunki pracy, [w:] Prawo pracy w RP w obliczu przemian, red. M. Matey-Tyrowicz, T. Zieliński, Warszawa 2006, s. 233. 
podstawą zatrudnienia takich osób powinien być kontrakt menadżerski, który pozwala na uzależnienie bytu zatrudnionego od osiąganych przez niego efektów w pracy-zysków.

Podsumowując, należy stwierdzić, że zapoczątkowana w epoce PRL instytucja powołania jako podstawy pracowniczego zatrudnienia, biorąc pod uwagę zakres podmiotowy jej stosowania i treść stosunku pracy, przebyła długą drogę. Jednocześnie należy zauważyć, że wciąż sprawdza się w instytucjach i organach, których cechą charakterystyczną jest oparcie na sprawdzonych i zaufanych osobach oraz możliwość podjęcia natychmiastowej decyzji o odsunięciu pracownika od powierzonych mu zadań. W tym kontekście powołanie realizuje pierwotne cele, które przyświecały jego wprowadzeniu do systemu prawa pracy.

\section{BIBLIOGRAFIA}

Borek-Buchajczuk R., Powołanie niewłaściwe, „Praca i Zabezpieczenie Społeczne” 2011, nr 1. Kłosiewicz P., Instytucja powołania a powołanie pozorne, „Państwo i Prawo” 1966, nr 6.

Liszcz T., Dyrektor przedsiębiorstwa państwowego w PRL, Lublin 1986.

Liszcz T., Pozaumowne stosunki pracy, [w:] Prawo pracy $w$ RP w obliczu przemian, red. M. Matey-Tyrowicz, T. Zieliński, Warszawa 2006.

Sanetra W., [w:] Prawo w XXI wieku. Księga pamiątkowa 50-lecia Instytutu Nauk Prawnych PAN, red. W. Czapliński, Warszawa 2006.

Stelina J., Charakter prawny stosunku pracy z mianowania, Gdańsk 2005.

Zieliński T., Stosunek prawa pracy do prawa administracyjnego, Warszawa 1977.

\section{SUMMARY}

The article was made to analyze the causes as the basis for the introduction of the appointment of an employment relationship to the Polish legal system and the evolution of its subjective scope. Launched in the era of communist organization as a basis for the establishment of Staff Employment, taking into account the personal scope of its application and the content of the employment relationship has come a long way. At the same time, it is clear that he still works in the institutions and bodies whose characteristic activity is back on the tried and trusted people and the possibility of taking an immediate decision on the removal of the employee from his tasks. The article indicates groups of positions covered by appointment and justification for leaving the base of the employment relationship in the Labour code in spite of far-reaching political changes.

Keywords: appointment, Labour code 